\title{
Nursing training on the administration of medication in pediatrics: an assessment of observed and self-reported behavior
}

\author{
Treinamento para enfermagem sobre administração de medicamentos na pediatria: avaliação do \\ comportamento observado e autorreferido \\ Entrenamiento para enfermería sobre administración de medicamentos en la pediatría: evaluación del \\ comportamiento observado y autorreferencia
}

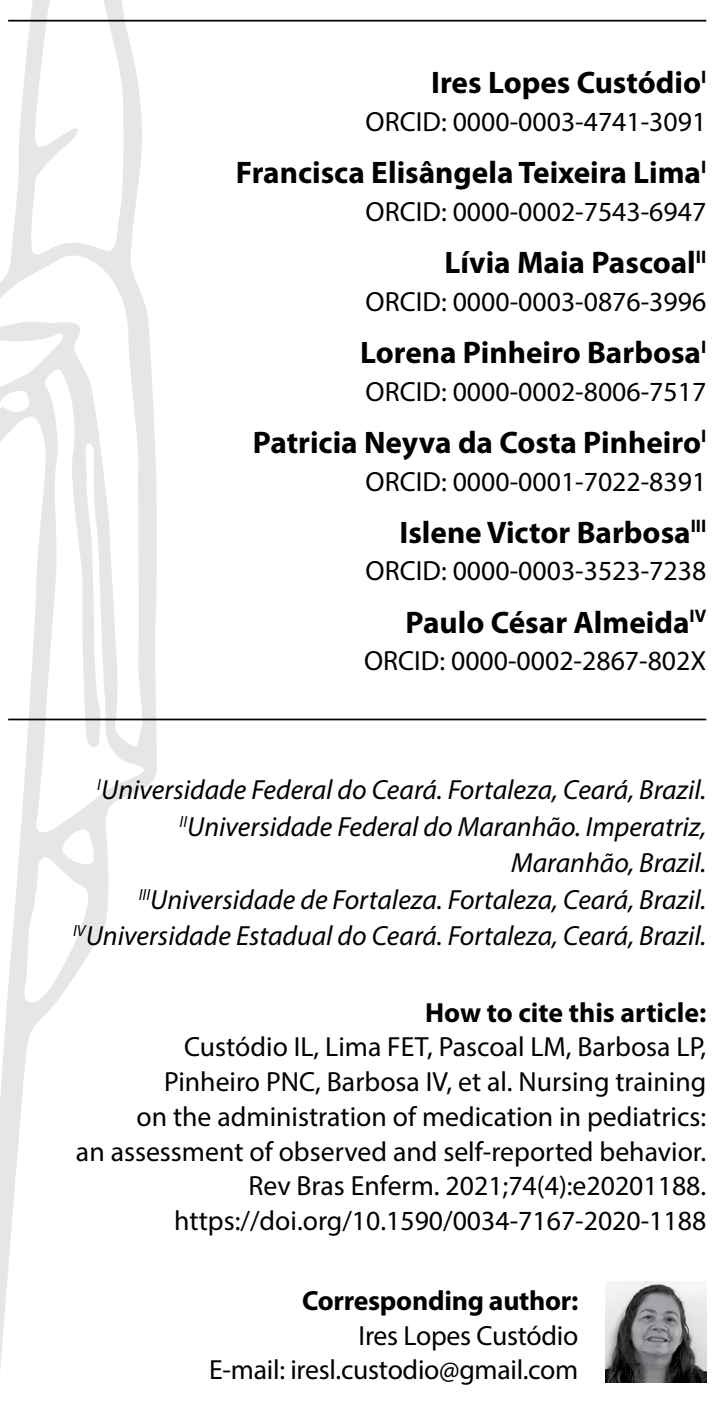

EDITOR IN CHIEF: Antonio José de Almeida Filho ASSOCIATE EDITOR: Fátima Helena Espírito Santo

Submission: $11-14-2020$

Approval: $01-26-202$

\begin{abstract}
Objectives: to evaluate the effect of a training program on the administration of intravenous drugs in pediatric patients on the observed and self-reported behavior of the nursing team. Methods: evaluation study carried out with 38 professionals during three phases: Assessment of the behavior observed in the actions performed before training; Training implementation; and Assessment of observed and self-reported behaviors (immediately and six months after training). Results: in the observed behavior, there was an improvement in six (6/12) hand hygiene actions; five (5/14) pertaining to environment Organization, selection, and preparation of materials; and in seven (7/10) referring to the Orientation of the procedure, administration and monitoring of the patient's reactions. In self-reported behavior, there was an improvement in two (2/8) actions. Conclusions: the training resulted in an improvement in the actions of nursing professionals related to the administration of intravenous medications, both in observed and in self-reported behavior.
\end{abstract}

Descriptors: Inservice Training; Nursing Team; Educational Measurement; Patient Safety; Health Promotion.

\section{RESUMO}

Objetivos: avaliar o efeito de um programa de treinamento sobre administração de medicamentos endovenosos em pacientes pediátricos no comportamento observado e autorreferido da equipe de enfermagem. Métodos: estudo avaliativo realizado com 38 profissionais em três fases: Avaliação do comportamento observado nas ações realizadas antes do treinamento; Implementação do treinamento; e Avaliação dos comportamentos observado e autorreferido (imediatamente e seis meses após treinamento). Resultados: no comportamento observado, houve melhora em seis (6/12) ações de Higienização das mãos; cinco (5/14) de Organização do ambiente, seleção e preparo de materiais; e em sete $(7 / 10)$ referentes à Orientação do procedimento, administração e monitoramento das reações do paciente. No comportamento autorreferido, houve melhora em duas (2/8) ações. Conclusões: o treinamento repercutiu em melhora nas ações dos profissionais de enfermagem relacionadas à administração de medicamentos por via endovenosa, tanto no comportamento observado quanto no autorreferido.

Descritores: Treinamento em Serviço; Equipe de Enfermagem; Avaliação Educacional; Segurança do Paciente; Promoção da Saúde.

\section{RESUMEN}

Objetivos: evaluar efecto de programa de entrenamiento sobre administración de medicamentos endovenosos en pacientes pediátricos en el comportamiento observado y autorreferencia del equipo de enfermería. Métodos: estudio evaluativo realizado con 38 profesionales en tres fases: Evaluación del comportamiento observado en las acciones realizadas antes del entrenamiento; Implementación del entrenamiento; y Evaluación de los comportamientos observado y autorreferencia (inmediatamente y seis meses después del entrenamiento). Resultados: en el comportamiento observado, hubo mejora en seis (6/12) acciones de Higienización de las manos; cinco (5/14) de Organización ambiental, selección y preparo de materiales; $y$ en siete $(7 / 10)$ referentes a la Orientación del procedimiento, administración y monitoreo de las reacciones del paciente. En el comportamiento autorreferencia, hubo mejora en dos (2/8) acciones. Conclusiones: el entrenamiento repercutió en mejora en las acciones de los profesionales de enfermería relacionadas a la administración de medicamentos por vía endovenosa, tanto en el comportamiento observado cuanto en la autorreferencia. Descriptores: Capacitación en Servicio; Grupo de Enfermería; Evaluación Educacional; Seguridad del Paciente; Promoción de la Salud. 


\section{INTRODUCTION}

To promote the knowledge and skill of an individual or group, it is necessary to train with the purpose of improving knowledge, skills, and attitudes, in such a way as to make him/them competent ${ }^{(1)}$. The development of competencies for health promotion allows reflection on practices and contributes to the process of permanent change, in which one learns by doing, continuously and daily, which favors learning through the approximation to the population and the development of autonomy and a critical vision ${ }^{(2)}$.

"Training" can be conceptualized as a planned effort to develop the employee's skills and abilities, which will be converted into better performance in the assignments, functions, and activities developed in the work environment ${ }^{(3)}$. To consider an effective training program, it is necessary to evaluate it, as this provides the organizers with guidance on the importance of training in reaching knowledge, changing behavior, and results generated at work; and this assessment can be carried out at four levels: Level 1 - Reaction; Level 2 - Learning; Level 3 - Behavior; and Level 4 - Results ${ }^{(1)}$. Behavioral assessment is perceived when participants change their own behavior as a result of participating in training ${ }^{(1)}$, and it is necessary to confirm that knowledge, skills, and attitudes have been learned and implemented in the work environment ${ }^{(3)}$.

The administration of medication is one of the most critical processes in hospital care, in addition to being the main resource used in the treatment of diseases. According to Law No. 7,498 (4), nursing professionals must continually improve their skills to ensure patient safety ${ }^{(5)}$. Thus, conducting training is important because it favors knowledge and encourages practice. The assessment carried out at the end of training is relevant to verify whether the desired results are achieved for both the professionals and organization ${ }^{(1)}$.

In pediatrics, studies show that the probability of a potential harmful incident with intravenous drugs is three times higher in hospitalized children when compared to adult patients ${ }^{(6)}$, due to organ immaturity and the variation in weight and body surface ${ }^{(7)}$.

For this reason, we highlight the importance of the nursing team in this segment to guarantee safe assistance, since it is the last line of defense capable of preventing possible damage to the patient resulting from the medication process ${ }^{(5)}$. On this topic, a study on the prevention of adverse events in pediatrics identified incident rates between $0.91 \%$ and $54 \%{ }^{(6)}$. The high occurrence of incident reporting in this clientele represents an important indicator to assess the safety and quality of the health system ${ }^{(5)}$.

The assessment of the nursing team's behavior in drug therapy after training can reveal the weak points of pediatric health care and encourage professionals to reconsider their practice and the need to restructure their work processes ${ }^{(8)}$.

Incidents with medication, notably intravenous, should not be taken lightly, and it is essential to establish risk reduction strategies ${ }^{(9)}$. Therefore, the need is reinforced both for continuous training and the implementation of technologies to standardize and prevent incidents, and for initiatives to promote the safety and quality of health care, whether for this clientele, or for the family and professionals involved ${ }^{(10)}$.

\section{OBJECTIVES}

To evaluate the effect of a training program on the administration of intravenous drugs in pediatric patients on the observed and self-reported behavior of the nursing team.

\section{METHODS}

\section{Ethical aspects}

The study was approved by the Research Ethics Committee. Patients agreed to participate by signing the Free and Informed Consent Form. Anonymity of the observations made was guaranteed to the participants to avoid embarrassment; in addition, although the researcher has positioned herself close to the medication preparation and administration location to observe the stages of the process, a certain distance was maintained so as not to interfere with the execution by the professional.

\section{Study design, period, and location}

Evaluative study, guided by the STROBE tool, carried out from June 2018 to January 2019, in a public hospital that is part of the National Network of Sentinel Hospitals [Hospitais Sentinela], of the National Health Surveillance Agency. Three pediatric cardiology units were contemplated: Pediatric Inpatient Unit, Pre-Operative and Post-Operative Pediatric Intensive Care Unit. To this end, the nursing team involved in this process participated in training on the administration of intravenous drugs to promote the safety of pediatric patients in the hospital environment.

\section{Population or sample, inclusion and exclusion criteria}

The population consisted of 120 professionals from the nursing team working in healthcare practice; the sample was of 38 professionals (20 nurses and 18 nursing technicians). The inclusion criteria were the following: to participate in the process of administering intravenous drugs (ID) in the pediatric cardiological unit for at least six months and accept to participate in training on the established days. Exclusion criteria: being on vacation, on leave or away from their activities, and not having participated in all stages of the study.

\section{Study protocol}

The study was developed in three phases: 1 - Evaluation of the behavior observed in the actions performed by the nursing team before training; 2 - Training implementation; 3 - Assessment of the behavior observed in the actions performed by the nursing team and an assessment of the self-reported behavior, immediately and six months after training.

In Phase 1, the observed behavior of the participants was identified via a checklist ${ }^{(11)}$, based on the already developed and validated Prescription, Use, and Administration of Medicines Proto$\mathrm{col}^{(5)}$, containing four steps: 1 - Reading of the medical prescription (3 actions); 2 - Hand hygiene (12 actions); 3 - Organization of the environment, selection, and preparation of intravenous medication material (14 actions); and 4 - Guidance on the procedure, 
administration, and monitoring of patient's reactions to intravenous medication (10 actions). To collect data on observed behavior, the convenience sampling technique was used, that is, the researcher waited for intravenous medication to be administered. She always positioned herself close to the location and observed the steps of the process recorded in the checklist ${ }^{(11)}$.

In Phase 2, training was implemented by six nurse instructors, in a single face-to-face meeting, through an expository dialogued class, lasting three hours, totaling 23 individual and 5 collective meetings, in different shifts and days, to allow for the participation of the maximum number of professionals. In training, the Prescription, Use, and Administration of Medicines Protocol contents ${ }^{(5)}$ and the adapted manual of the Protocol on the Medicine Administration Process ${ }^{(12)}$ were addressed, aimed at the topic of administration of intravenous drugs in pediatrics, contemplating the following items: 1 ) Reading of the medical prescription; 2) Hand hygiene; 3) Organization of the environment and selection of materials (preparation of the appropriate material); 4) Preparation of intravenous medication; 5) Providing guidance on the procedure for children and/or companions; and 6) Technique for administering and monitoring patient's reactions to intravenous drugs.

In Phase 3, a questionnaire was applied immediately and six months after training, when the level of self-reported behavior was assessed. This questionnaire was designed, adapted, and validated based on the Prescription, Use, and Administration of Medicines Protocol ${ }^{(5)}$ and the guidelines for creating an effective form for assessing behavior ${ }^{(1)}$. It contains nine items distributed on a Likert scale: 1 (much less), 2 (slightly less), 3 (equal), 4 (slightly more), and 5 (much more). Answers 1,2 , and 3 were considered inadequate; and as adequate, 4 and 5. The agreement of correct answers were those with values greater than or equal to $80 \%{ }^{(13)}$. Also, in this phase, six months after training, the observed behavior of the nursing professionals in the process of administering the intravenous medication was again evaluated, using the same checklist ${ }^{(11)}$ of Phase 1.

\section{Analysis of results and statistics}

The data were processed in SPSS 20.0, license No. 1010113007, organized in tables with the absolute and relative frequencies, means, and standard deviations of the quantitative variables. The before and after comparison of proportions was analyzed by the McNemar test, with $p<0.05$ analyses being considered statistically significant.

\section{RESULTS}

In the characterization of the professionals, there was a predominance of women (100\%), nurses $(52.6 \%)$, with a mean age of 41.26 ( \pm 11.8 ) years, professionals with postgraduate degrees (52.6\%), and average experience of 13.11 ( \pm 8.3 ) years. Professional experience with intravenous medication averaged $11.63( \pm 7.1)$ years. The monthly workload varied from 86 to 360 hours, with an average of 168.84 ( \pm 57.8$)$. The professionals worked mainly in the morning and afternoon shifts (day shift) (52.6\%). Most of the nurses replied that they took an intravenous medication system course (78.9\%), and only $47.4 \%$ took this course for pediatric patients with heart disease. In addition, the majority knew the existence of the unit's standard operating procedure (89.5\%) and claimed to have consulted it (63.2\%).

The nursing team professionals were observed in the performance of 39 actions related to the process of administering intravenous drugs. When evaluating the actions Reads medical prescription, Understands spelling, and Checks name, it was found that, before and after training, all were performed by nursing professionals with values greater than or equal to $80 \%$ correct.

Table 1 shows the 12 actions related to hand hygiene observed before and after training.

In hand hygiene, improvement was noted after training in the following actions: removes adornments $(p<0.0001)$, scrubs back of hand $(p<0.021)$, rubs palm with palm $(p=0.003)$, washes back of fingers ( $p<0.0001)$, rubs thumbs $(p<0.0001)$, and hand washing for over 30 seconds $(p<0.0001)$.

Table 2 shows the 14 actions for organizing the environment, selecting, and preparing the material for intravenous medication.

As noted in Table 2, the percentage of improvement after training increased in the actions: bench cleanliness and organization $(p<0.0001)$, possesses a kidney dish or tray $(p=0.013)$, disinfection of the ampoule/vial ( $p<0.0001$ ), medication reconstitution respecting hospital infection prevention $(p=0.001)$, and preparing medication for continuous infusion $(p=0.004)$.

Table 3 contains the ten actions for guidance on medication administering and monitoring patient's reactions related to intravenous medication.

Table 1 - Distribution of the number of professionals according to hand hygiene before and after training, Fortaleza, Ceará, Brazil, 2018-2019

\begin{tabular}{|c|c|c|c|c|c|}
\hline \multirow[b]{2}{*}{ Action } & \multicolumn{2}{|c|}{ Before Training } & \multicolumn{2}{|c|}{ After Training } & \multirow[b]{2}{*}{$\boldsymbol{p}^{*}$} \\
\hline & $\begin{array}{c}\text { Yes } \\
\text { n (\%) }\end{array}$ & $\begin{array}{c}\text { No } \\
\text { n (\%) }\end{array}$ & $\begin{array}{c}\text { Yes } \\
\text { n (\%) }\end{array}$ & $\begin{array}{c}\text { No } \\
\text { n (\%) }\end{array}$ & \\
\hline Removes adornments & $24(63.2)$ & $14(36.8)$ & $31(81.6)$ & $7(18.4)$ & $<0.0001$ \\
\hline Wets hands & $37(97.4)$ & $1(2.6)$ & $37(97.4)$ & $1(2.6)$ & 1.000 \\
\hline Uses enough soap & $37(97.4)$ & $1(2.6)$ & $38(100)$ & - & 1.000 \\
\hline Rubs palm & $38(100)$ & - & $36(94.7)$ & $2(5.3)$ & 1.000 \\
\hline Scrubs back of hand & $28(73.7)$ & $10(26.3)$ & $36(94.7)$ & $2(5.3)$ & 0.021 \\
\hline Rubs palm with palm & $26(68.4)$ & $12(31.6)$ & $37(97.4)$ & $1(2.6)$ & 0.003 \\
\hline Washes back of fingers, closing them over the palm & $11(28.9)$ & $27(71.1)$ & $35(92.1)$ & $3(7.9)$ & $<0.0001$ \\
\hline Rubs thumbs & $19(50.0)$ & $19(50.0)$ & $37(97.4)$ & $1(2.6)$ & $<0.0001$ \\
\hline Holds hands under running water & $37(97.4)$ & $1(2.6)$ & $38(100)$ & - & 1.000 \\
\hline Dries hands & $35(92.1)$ & $3(7.9)$ & $36(94.7)$ & $2(5.3)$ & 1.000 \\
\hline Uses paper towel to turn off faucet & $29(76.3)$ & $9(23.7)$ & $36(94.7)$ & $2(5.3)$ & 0.065 \\
\hline Hand washing for over 30 seconds & $12(31.6)$ & $26(68.4)$ & $33(86.8)$ & 5 (13.2) & $<0.0001$ \\
\hline
\end{tabular}


Table 2 - Distribution of the number of professionals according to organization and selection of material before and after training, Fortaleza, Ceará, Brazil, 2018-2019

\begin{tabular}{|c|c|c|c|c|c|}
\hline \multirow[b]{2}{*}{ Action } & \multicolumn{2}{|c|}{ Before Training } & \multicolumn{2}{|c|}{ After Training } & \multirow[b]{2}{*}{$\boldsymbol{p}^{*}$} \\
\hline & $\begin{array}{c}\text { Yes } \\
\text { n (\%) }\end{array}$ & $\begin{array}{c}\text { No } \\
\text { n (\%) }\end{array}$ & $\begin{array}{c}\text { Yes } \\
\text { n (\%) }\end{array}$ & $\begin{array}{c}\text { No } \\
\text { n (\%) }\end{array}$ & \\
\hline Bench cleanliness and organization & $16(42.1)$ & $22(57.9)$ & $35(92.1)$ & $3(7.9)$ & $<0.0001$ \\
\hline Possesses a kidney dish or tray & $23(60.5)$ & $15(39.5)$ & $33(86.8)$ & $5(13.2)$ & 0.013 \\
\hline Use of personal protective equipment (PPE) & $30(78.9)$ & $8(21.1)$ & $36(94.7)$ & $2(5.3)$ & 0.109 \\
\hline Chooses syringe & $35(92.1)$ & $3(7.9)$ & 37 (97.4) & $1(2.6)$ & 0.625 \\
\hline Selects needle for aspiration & $38(100)$ & - & $38(100)$ & - & 1.000 \\
\hline Checks label (correct drug) & $33(86.8)$ & $5(13.2)$ & $36(94.7)$ & $2(5.3)$ & 0.453 \\
\hline Checks the integrity of equipment /medication seal & $33(86.8)$ & $5(13.2)$ & $35(92.1)$ & $3(7.9)$ & 1.000 \\
\hline Inspects ampoule/vial & $29(76.3)$ & $9(23.7)$ & $33(86.8)$ & $5(13.2)$ & 0.388 \\
\hline Observes expiration date & $34(89.5)$ & $4(10.5)$ & $38(100)$ & - & 1.000 \\
\hline Disinfection of the ampoule/vial & $22(57.9)$ & $15(39.5)$ & $35(92.18)$ & $3(7.9)$ & $<0.0001$ \\
\hline Medication reconstitution respecting hospital infection prevention & $16(42.1)$ & $22(57.9)$ & $38(100)$ & - & 0.001 \\
\hline Prepares medication for continuous infusion & $21(55.3)$ & $17(44.7)$ & $34(89.5)$ & $4(10.5)$ & 0.004 \\
\hline Attributes identification of the prepared medication & $30(78.9)$ & $8(21.1)$ & $36(94.7)$ & $2(5.3)$ & 0.109 \\
\hline Proper disposal of materials used during preparation & $37(97.4)$ & $1(2.6)$ & 37 (97.4) & $1(2.6)$ & 1.000 \\
\hline
\end{tabular}

Note: *McNemar test.

Table 3 - Distribution of the number of professionals according to medication administering and monitoring patient's reactions before and after training, Fortaleza, Ceará, Brazil, 2018-2019

\begin{tabular}{|c|c|c|c|c|c|}
\hline \multirow[b]{2}{*}{ Action } & \multicolumn{2}{|c|}{ Before Training } & \multicolumn{2}{|c|}{ After Training } & \multirow[b]{2}{*}{$\boldsymbol{p}^{*}$} \\
\hline & $\begin{array}{c}\text { Yes } \\
\text { n (\%) }\end{array}$ & $\begin{array}{c}\text { No } \\
\text { n (\%) }\end{array}$ & $\begin{array}{c}\text { Yes } \\
\text { n (\%) }\end{array}$ & $\begin{array}{c}\text { No } \\
\text { n (\%) }\end{array}$ & \\
\hline Informs the patient/companion about the procedure & $12(31.6)$ & $26(68.4)$ & $28(73.7)$ & $10(26.3)$ & 0.001 \\
\hline Calms the patient & $22(57.9)$ & $16(42.1)$ & $37(97.4)$ & $1(2.6)$ & $<0.0001$ \\
\hline Checks medication (correct delivery method, dose, and way) & 30 (78.9) & $8(21.1)$ & $38(100)$ & - & $<0.0001$ \\
\hline Checks name (correct patient) & $38(100)$ & - & $38(100)$ & - & $<0.0001$ \\
\hline Installs the medication (at right time) & $28(73.7)$ & $10(26.3)$ & $36(94.7)$ & $2(5.3)$ & 0.021 \\
\hline Keeps patient comfortable & $32(84.2)$ & $6(15.8)$ & 36 (94.7) & $2(5.3)$ & 1.000 \\
\hline Immediately registers/checks-in patient (correct registration) & $35(92.1)$ & $3(7.9)$ & $37(97.4)$ & $1(2.6)$ & 0.625 \\
\hline Monitors patient (correct response to treatment) & $33(86.8)$ & $5(13.2)$ & $36(94.7)$ & $2(5.3)$ & 0.453 \\
\hline $\begin{array}{l}\text { explains adverse reactions and required care after drug administration, } \\
\text { if necessary }\end{array}$ & $11(28.9)$ & $27(71.1)$ & $23(60.5)$ & $15(39.5)$ & 0.008 \\
\hline Proper disposal of materials used after administration & $14(36.8)$ & $24(63.2)$ & $35(92.1)$ & $3(7.9)$ & $<0.0001$ \\
\hline
\end{tabular}

Note: *McNemar test.

Table 4 - Distribution of the number of professionals according to the assessment of self-reported behavior immediately and six months after training, Fortaleza, Ceará, Brazil, 2018-2019

\begin{tabular}{|c|c|c|c|c|c|}
\hline $\begin{array}{l}\text { Self-reported behavior of the nursing team to work in the } \\
\text { intravenous drug administration process }\end{array}$ & $\begin{array}{c}\text { Immediately } \\
\text { Inadequate } \\
\text { n (\%) }\end{array}$ & $\begin{array}{c}\text { fter training } \\
\text { Adequate } \\
\text { n (\%) }\end{array}$ & $\begin{array}{c}\text { Six months } \\
\text { Inadequate } \\
\mathbf{n}(\%)\end{array}$ & $\begin{array}{l}\text { er training } \\
\text { Adequate } \\
\text { n (\%) }\end{array}$ & $\boldsymbol{p}^{*}$ \\
\hline Interest in the subject & $11(29)$ & $27(71.0)$ & $2(5.3)$ & $36(94.7)$ & 0.012 \\
\hline Sensitivity & $12(31.6)$ & $26(68.4)$ & $4(10.5)$ & $34(89.5)$ & 0.039 \\
\hline Knowledge & $2(5.3)$ & 36 (94.7) & $2(5.3)$ & $36(94.7)$ & 1.000 \\
\hline Commitment & $2(5.3)$ & $36(94.7)$ & $4(10.5)$ & $34(89.5)$ & 0.687 \\
\hline Capacity & $4(10.5)$ & $34(89.5)$ & $3(7.9)$ & $35(92.1)$ & 1.000 \\
\hline Feels prepared & $4(10.5)$ & $34(89.5)$ & $1(2.6)$ & $37(97.4)$ & 0.375 \\
\hline Behavior was modified in professional practice & $4(10.5)$ & $34(89.5)$ & $2(5.3)$ & $36(94.7)$ & 0.686 \\
\hline Believed training was useful & $2(5.3)$ & $36(94.7)$ & $1(2.6)$ & 37 (97.4) & 1.000 \\
\hline
\end{tabular}

Note: *McNemar test.

After the training, the actions that showed improvement were: Informs the patient/companion about the procedure $(p=0.001)$, calms the patient $(p<0.0001)$, checks medication $(p<0.0001)$, checks name ( $p<0.0001$ ), installs medication (at right time) ( $p$ $=0.021$ ), explains adverse reactions and required care after drug administration, if necessary ( $p=0.008)$, and proper disposal of materials used after administration ( $p<0,0001)$.

Table 4 shows the self-reported behavior by nursing professionals regarding their role in the process of administering intravenous medication.

When assessing the professionals' self-reported behavior, immediately and six months after training, it was observed that, in general, most responses were adequate (> 80\%). However, a statistically significant increase in adequacy was identified in the questions Interest in the subject $(p=0.012)$ and in the Sensitivity to work in the process of administering intravenous drugs ( $p=$ 0.039) (Table 4).

\section{DISCUSSION}

\section{Assessment of the observed behavior of nursing profes- sionals during the actions of the process of administration of intravenous medication}

When evaluating the 39 actions related to the process of administering intravenous drugs, an adequate performance of the 
nursing team was observed in the actions of reading the medical prescription, since $100 \%$ of the professionals performed it before and after the training. A study that evaluated the preparation and administration of oral medications by nursing professionals to institutionalized children obtained similar results, as they read the prescription (100\%), managed to understand the spelling of the medical prescription (96.3\%), and checked the child's name relating it to the prescription (100\%). Therefore, it appears that these actions performed by nursing professionals contribute to the promotion of safety for institutionalized children ${ }^{(14)}$.

However, literature shows a great predominance of errors in medical prescription, especially in drugs that require weight-based dosing, requiring the development of a specific prescription instrument for pediatrics, which favors the agreement of the actions taken in cases of error detection ${ }^{(7)}$.

In the present study, there was a greater adherence by professionals in actions related to hand hygiene after six months of training. There was an improvement in the success rates, higher than $80 \%$, which demonstrates that the training, in addition to favoring the learning of participants, made them aware of the need for hand hygiene in the process of administering intravenous drugs in the hospital environment.

Hand hygiene is a simple and efficient measure in the prevention of nosocomial infection, especially cross infection, as well as in promoting the safety of patients, professionals, and other users of health services. Hand hygiene is the first step towards safety and excellence in the quality of patient care ${ }^{(15)}$. Thus, professionals should wash their hands before and after the preparation and administration of parenteral medications, following the recommendations of the Commission for Infection Control in Health Services ${ }^{(16)}$.

In the organization of the environment, selection, and preparation of the intravenous medication material, a greater adherence by professionals in this practice was found in all the actions evaluated in this study when comparing the results before and after training. The organization of the material is an important and essential aspect in the medication administration process, as it implies patient safety. On this subject, a study that evaluated the performance of the nursing team in the organization of the environment, in the preparation and dilution of drugs administered intramuscularly in pediatrics found that, in the organization of the environment, satisfactory performance was achieved in the actions: organizing the bench (70.6\%), choosing a syringe compatible with the volume to be administered (80.7\%), adequately selecting the aspiration needle (71.2\%) and the needle for administering (97.8\%), changing the needle after preparation $(81.3 \%)$, and medication reconstitution in distilled water $(100 \%)^{(17)}$.

In the preparation of the material and intravenous medication, all actions showed correct performance above $80 \%$, immediately and six months after training, and this demonstrates that the training favored the professionals' learning and sensitized them to change their behavior when adhering to the actions of medication preparation, according to the recommendations of the Safety Protocol on Prescription, Use, and Administration of Medicines ${ }^{(5)}$. To perform these actions, professionals must focus on reading and interpreting each item of the medical prescription, avoiding being dispersed by noise ${ }^{(5)}$, as well as developing and implementing permanent education programs to promote patient safety ${ }^{(18)}$.

In the preparation and administration of parenteral solutions, the recommendations of the Commission for Infection Control in Health Services should be followed regarding hand hygiene, disinfection of the environment and surfaces, use of PPE, and disinfection of ampoules, flasks, medication connection points and infusion line connections ${ }^{(16)}$. A study that sought to identify the main incidents in the preparation of intravenous drugs grouped them into the following categories: changing needles, disinfecting ampoules, bench cleanliness, and incorrect administering time and dose. Incident rates were higher than $50 \%$ in all categories, except for incorrect dose $(6.58 \%)^{(19)}$.

In the present study, the positive results stand out regarding the actions related to the orientation of the procedure, administration, and monitoring of patient's reactions, since the majority presented statistically significant results in the behavior observed after training $(p<0.05)$. In this sense, the Ministry of Health highlights the importance of communication for guidance and clarification of patient questions, favoring the prevention of adverse events ${ }^{(5)}$.

Communication failure is common in medication administration, with a low incidence of performing the act of introducing oneself to a child and/or guardian (0.9\%) during the activity, showing a communication deficit between the professional and the patient and/or companion, which can trigger error and damage ${ }^{(20)}$.

A study on the compatibility, types, and frequency of errors in the preparation and administering of intravenous drugs showed that the most frequent errors were "hand hygiene" and "non-use of aseptic technique", pointing to the need to develop and implement programs of permanent education focused on patient safety ${ }^{(18)}$

Among the observed actions of medication administration and monitoring of patient's reactions, five obtained a statistically significant difference $(p<0.05)$. A survey concluded that not all actions are carried out in the medication administration process, making it necessary to train nursing professionals with a view to promoting patient safety in the hospital environment. The predominant actions in that study were: installs medication or serotherapy according to the prescription (93.9\%), properly disposes of the materials used (89.3\%), and records it in the medical record immediately after administering medication $(86.8 \%)^{(21)}$.

Another cross-sectional survey that was carried out with pediatric nurses from 14 hospitals in Madrid obtained a result that is similar to that of the present investigation, since, of the 114 participants who answered the self-administered questionnaire, $80(70.8 \%)$ said they verified the doses prior to administering them, and 20 (18.6\%) reported not believing that they would be held responsible for administering a poorly prescribed dose ${ }^{(22)}$.

Another way of ensuring patient safety is double checking, which was performed and recorded by the nursing professionals participating in the present study. This result differs from that found in a study in which professionals pointed out weaknesses in the practice of double checking of medications ${ }^{(7)}$.

In addition, it is worth noting that the institution in which the research was developed consists of a teaching hospital, a reference in complex care, which disposes of a dedicated nurse for 
permanent education in the pediatric sectors and has Standard Operating Procedures (SOP) and flow charts on patient safety protocols, which are constantly evaluated by patient safety commissions. Therefore, although professionals have limitations on the topic and do not have the habit or even time to read the recommendations of SOPs and flowcharts, this practice should be encouraged in order to ensure compliance with good practices that prevent breaking barriers for disease prevention. It is important to highlight that, although the results obtained in this study show that the training contributed to the professionals' adherence in some actions recommended in the safe medication administration process, all practices involving patient safety in the care process must be complied with, and not just a few.

\section{Assessment of self-reported behavior by the nursing team}

In this study, it was noticed that most of the responses that assessed the self-reported behavior by nursing professionals after training on the process of administering intravenous drugs in hospitalized pediatric cardiac patients were satisfactory.

This finding corroborates what was pointed out in a study carried out with eight nurses from the rural area of Ceará, who evaluated their reaction and behavior after training on the use of an educational tool to promote healthy nutrition for children, since all of them (100\%) were satisfied with the training. In the analysis of behavior, more than half of the nurses $(87.5 \%)$ achieved the expected performance, and the training was considered effective, as the participants demonstrated satisfaction and the majority considered themselves capable of using the educational tool to motivate children to eat healthy ${ }^{(23)}$.

In order for educational programs to promote changes in the behavior of their participants, so as to modify their work dynamics in order to improve processes, eliminate methodological flaws, expand theoretical concepts, namely motivate them to work, it is necessary to measure the degree of success of these educational programs based on behavioral assessments. Assessing behavior indicates the extent to which behavior change has occurred - for example, after undergoing training ${ }^{(1)}$.

It is worth noting that the positive results in the professionals' behavioral evaluations after training become positive impacts on these participants. In such context, a survey that assessed social skills, behaviors, and contexts for college students noted that most participants could identify difficulties in behaviors that are components of factors such as expressing negative feelings, opinions, and dealing with criticism; and indicated that the evaluation is more accurate when assessing the frequency and quality with which the behaviors are emitted, in face of different situations and interlocutors ${ }^{(24)}$.

Training facilitators, when conducting the participants behavior assessment, should try to determine whether the failure to effectively apply what was learned was caused by inadequate or irrelevant training, or by a lack of support from the work environment, as, in general, there is a culture that is inapt at supporting and reinforcing learning ${ }^{(1)}$. There are training participants capable of changing their behavior right after they return to work; others can take some time to do this; but there will also be those who do not change. Therefore, it is important to repeat the assessment at the right time ${ }^{(1)}$.

When dealing with the topic of intravenous drug administration, it is worth noting that regular assessment, in addition to providing progressive and experienced data, acts as a continuous reinforcement. Many participants will put aside the desired behaviors if they know that no one is watching them ${ }^{(1)}$.

A study revealed that $63.9 \%$ of the research participants (nursing technicians and nurses) stated that they had not participated in courses and lectures on preparation and administration of medications in the last year, and that the majority had doubts regarding the effects of the medications and referred to colleagues for such answers, instead of the reference nurse ${ }^{(7)}$.

So, it is suggested that, for a quality and safe assistance, it is necessary that work processes are reviewed based on scientific evidence and that professionals are trained, incorporating leaders and followers ${ }^{(7)}$, based on educational strategies, and using various technologies, such as focus groups or educational websites and simulation games, as they favor the reduction of medicationrelated incidents ${ }^{(22)}$.

Therefore, it is necessary to encourage and sensitize professionals to participate in educational strategies, with a view to expanding knowledge about risk factors and patient safety and the implementation of safety barriers, resulting in safe care for hospitalized pediatric patients ${ }^{(10)}$.

\section{Study limitations}

There was only one assessment level in training (behavior) among the four levels; therefore, if all of these had been included, the educational intervention would have been more consistent ${ }^{(1)}$. In addition, the self-reported behavior assessment indicators were different from the observed behavior, which made it impossible to compare the professional's verbalization and the practice of administering intravenous drugs.

\section{Contributions to the field of nursing, health, or public policies}

After training, the nursing staff will be able to empower themselves with the process of administering intravenous drugs, develop their knowledge, skills, and attitudes with pediatric hospitalized cardiac patients to promote safe and high-quality technicalscientific care. It is emphasized that it is necessary to encourage these professionals to adopt behaviors that contribute to safe care.

\section{CONCLUSIONS}

It was concluded that, in the observed behavior, there was an improvement in performance in 18 (46.15\%) of the 39 actions of the three stages after training: Hand hygiene; Organization of the environment, and selection and preparation of medication material; and Orientation about the procedure, medication administration, and monitoring patient's reactions to the medication. In the self-reported behavior, there was an improvement in the items Interest in the subject and Sensitivity to work in the medication administration process. 


\section{REFERENCES}

1. Kirkpatrick DL, Kirkpatrick JD. Como avaliar programas de treinamento de equipes: os quatro níveis. Rio de Janeiro: Senac; 2010. 388 p.

2. Netto L, Silva KL, Rua MS. Competency Building for Health Promotion and Change in the Care Model. Texto Contexto Enferm. 2016;25(2):e2150015. https://doi.org/10.1590/0104-07072016002150015

3. Macena-Neto JB, Mota FPB. Treinamento e desenvolvimento nas organizações: estudo sobre a satisfação com o treinamento em uma instituição pública de ensino federal. Métodos e Pesquisa em Administração [Internet]. 2017 [cited 2020 Oct 20];2(2):47-61. Available from: https://periodicos.ufpb.br/index.php/mepad/article/view/36716

4. Conselho Regional de Enfermagem do Ceará (COREN). Lei nº 7.498, de junho de 1986. Dispõe sobre a Regulamentação do Exercício da Enfermagem e dá outras providências. Brasília: Ministério da Saúde; 1986.

5. Ministério da Saúde (BR). Fundação Oswaldo Cruz. Agência Nacional de Vigilância Sanitária. Protocolo de Segurança na Prescrição, Uso e Administração de Medicamentos (Anexo 3). [Internet]; Brasília: Ministério da Saúde. 2013 [cited 2020 Oct 20];1-46. Available from: http:// www.hospitalsantalucinda.com.br/downloads/prot_meficamentos.pdf

6. Volpatto BM, Wegner W, Gerhardt LM, Pedro ENR, Cruz SS, Bandeira LE. Erros de medicação em pediatria e estratégias de prevenção: revisão integrativa. Cogitare Enfermagem. 2017;22(1):e45132. https://doi.org/10.5380/ce.v22i1.45132

7. Manzo BF, Brasil CLGB, Reis FFT, Correa AR, Simão DAS, Costa ACL. Seguridad en la administración de medicamentos: investigación sobre la práctica de enfermería y circunstancias de errores. Enferm Glob. 2019;18(56):19-56. https://doi.org/10.6018/eglobal.18.4.344881

8. Belela ASC, Pedreira MLG, Peterlini MAS. Erros de medicação em pediatria. Rev Bras Enferm. [Internet]. 2011;64(3):563-9. https://doi. org/10.1590/S0034-71672011000300022

9. Billstein-Leber M, Carrillo CJD, Cassano AT, Moline K, Robertson JJ. ASHP guidelines on preventing medication errors in hospitals. Am J Health-Syst Pharm. 2018;75(19):1493-517. https://doi.org/10.2146/ajhp170811

10. Souza FT, Mayara CG, Pâmella PSR, Patrícia KR. Perception of nursing on the risk factors related to the pediatric patient safety. Rev Enferm UFSM. 2014;4(1):152-62. https://doi.org/10.5902/217976928781

11. Matias EO. Avaliação da prática de enfermagem no processo de administração de medicamento intravenoso na pediatria [Dissertação]. Fortaleza (CE): Universidade Federal do Ceará; 2015.

12. Barroso RFC, Moura AB, Barroso IFC (Colaboradores). Manual do Processo de administração de medicamentos endovenosos. Adaptação do Protocolo de Prescrição, uso e administração de medicamento do Ministério da Saúde de 2013, 2018. 58 p.

13. Pasquali L. Piscometria: teoria dos testes na psicologia e na educação. Petrópolis: Vozes; 2011. 180p.

14. Chaves CMP, Lima FET, Fernandes AFC, Matias ÉO, Araújo PR. Assessment of the preparation and administration of oral medications to institutionalized children. Rev Bras Enferm. 2018;71(suppl 3):1388-94. https://doi.org/10.1590/0034-7167-2017-0197

15. Agência Nacional de Vigilância Sanitária. Segurança do Paciente em Serviços de Saúde: Higienização das Mãos [Internet]; 2014 [cited 2020 Oct 20]. Available from: https://www20.anvisa.gov.br/segurancadopaciente/index.php/publicacoes/item/ seguranca-do-paciente-higienizacao-das-maos

16. Agência Nacional de Vigilância Sanitária. Dispõe sobre as bulas padronizadas de medicamentos específicos [Internet]. 2016 [cited 2020 Oct 20]. Available from: https://www.poderesaude.com.br/novosite/images/03.08.2016_l.pdf

17. Mota RO, Brito EAWS, Souza TLV, Farias LMVC, Matias ÉO, Lima FET. Preparo de medicamentos administrados via intramuscular na pediatria: atuação da equipe de enfermagem. Cogitare Enferm[Internet]. 2016 [cited 2020 Oct 20];21(esp):01-09. Available from: http://fi-admin. bvsalud.org/document/view/8dzr6

18. Mendes JR, Lopes MCBT, Vancini-Campanharo CR, Okuno MFP, Batista REA. Types and frequency of errors in the preparation and administration of drugs. Einstein (São Paulo). 2018;16(3):1-6. https://doi.org/10.1590/s1679-45082018ao4146

19. Camerini FG, Silva LD. Segurança do paciente: análise do preparo de medicação intravenosa em hospital da rede sentinela. Texto Contexto Enferm. 2011;20(1):41-9. https://doi.org/10.1590/S0104-07072011000100005

20. Souza TLV, Mota RO, Brito EAWS, Farias LMVC, Matias ÉO, Lima FET. Segurança do paciente na administração de medicamento intramuscular em pediatria: avaliação da prática de enfermagem. Rev Gaúcha Enferm. 2018;39:e2017-0002. https://doi. org/10.1590/1983-1447.2018.2017-0002

21. Costa DG, Pasin SS, Magalhães AMM, Moura GMSS, Rosso CB, Saurin TA. Analysis of the preparation and administration of medications in the hospital context based on Lean thinking. Rev Esc Anna Nery. 2018;22(4):e20170402. https://doi.org/10.1590/2177-9465-ean-2017-0402

22. Guerrero-Márquez G, Martínez-Serrano A, Míguez-Navarro C, López-Mirón JA, Espartosa-Larrayad M. Conocimiento de las enfermeras de las dosis de medicamentos en urgencias de pediatria. Enferm Clín. 2016;26(4):213-219. https://doi.org/10.1016/j.enfcli.2016.04.009

23. Ferreira AMV, Sabino LMM, Nascimento LA, Penha JC, Barbosa LP, Lima FET. Avaliação de reação e comportamento de enfermeiras após treinamento sobre alimentação infantil. Rev Bras Enferm. 2019;72(edição Suppl. 1):206-12. https://doi.org/10.1590/0034-7167-2017-0529

24. Bolsoni-Silva AT, Loureiro SR. Validação do Questionário de Avaliação de Habilidades Sociais, Comportamentos e Contextos para Universitários. Psicol: Teor Pesqui. 2016;32(2):e322211. https://doi.org/10.1590/0102-3772e322211 